\title{
DEVELOPMENT OF THE ANDALUSIAN GROUP IDENTITY
}

\section{EL DESARROLLO DE LA IDENTIDAD DE GRUPO ANDALUZA}

\author{
Marina Apaydin \\ The American University of Beirut \\ mapaydin@aucegypt.edu
}

Recibido: mayo, 2014.

Versión final aceptada: julio, 2014.

PALABRAS CLAVE: Al-Andalus, identidad de grupo, redes sociales informales.

KEY WORDS: Al-Andalus, group identity, informal social networks.

\section{RESUMEN}

A lo largo de sus 700 años de historia, Al-Andalus tuvo de forma consistente la imagen de "Paraíso terrenal" a pesar de sus continuos problemas económicos, sociales y políticos y amenazas externas. Este estudio intenta explicar cómo se creó la Identidad Andaluza, cuáles fueron sus principales características, porqué se consideraron un grupo que desarrollaba admiración y cómo esta información ha sido mantenida y transmitida a lo largo del tiempo.

Esta investigación tuvo lugar en 2005 en el Sur de España, zona antaño llamada AlAndalus. Una combinación de fuentes primarias y secundarias, junto a artefactos visuales de naturaleza histórica sirven de base para este análisis. La base teórica para este trabajo fue desarollada utilizando diferentes teorías sociales de los autores Bourdieu, Ringrose, Piaget, Cavalli-Sforza y Maslow.

\section{ABSTRACT}

Throughout its 700 years history, al-Andalus has consistently enjoyed an image of a "Paradise on Earth" in spite of its continuous internal economic, social and political problems and external threats. This paper attempts to uncover how the Andalusian group identity was formed, what its main characteristics were, why they were viewed as attractive and how this information was transmitted and maintained.

The research for this study was conducted in 2005 in Southern Spain, which used to be al-Andalus. A combination of primary and secondary sources, and historical visual artifacts were used as a basis for this analysis. Theoretical grounding for this work was developed based on several social theories of Bourdieu, Ringrose, Piaget, Cavalli-Sforza and Maslow.

ISSN: 0212-8594 ISSN-e: 2340-2776. № DOI: http://dx.doi.org/10.12795/rea.2014.i31.04 


\section{CONTEMPORARY PERCEPTION OF AL-ANDALUS.}

Al-Andalus is like Syria for its enjoyable climate and its air, like Yemen for its moderate and consistent temperature, like India for its penetrating perfumes, like Ahwaz for the importance of its agricultural income, like China for its precious stones, and like Aden for the useful products of its coast.

Abu ‘Ubayd al-Bakri, eleventh century geographer.

Since its inception in the eighth century until well after its disappearance in the fifteenth, al-Andalus has consistently enjoyed an image of a prosperous place, a "Paradise on Earth" in spite of its continuous internal economic, social and political problems and external threats. The land encountered by the conquering Muslim army was not much different in climate or natural resources from the rest of the Mediterranean; nor was the Visogothic kingdom was particularly prosperous in the beginning of the eighth century. Moreover, the conquerors represented only one or two percent of the indigenous population (Glick, T., 1979) and neither had a preconceived stratagem to make "a Paradise" from their new possessions, nor to advertise it as such to the rest of the world. So what did make al-Andalus so successful in projecting an attractive cohesive image so consistently from generation to generation?

This question is different from the one discussed in much literature before, which deals with the tangible success of the ruling class to exploit the riches of the land and its central trading position in order to build an economically prosperous state before its eventual break up into Taifa kingdoms. The question is about the creation of a perception that would survive even until modern times and inspire many romantically oriented Europeans to fanaticize about this land of wonders. To answer this question we first have to understand how the Andalusian group identity was formed, what its main characteristics were, why they were viewed as attractive and how this information was transmitted and maintained.

The social history of the world is, in the essence, a history of migration and mixing up of groups of peoples, resulting in derivative composite groups with various degrees of homogeneity. By the eleventh century an Andalusian identity with distinct cultural characteristics had been formed. What were the uniting basis and the contributing factors for the development of this identity? What were the distinctive ethnic groups, which have melted into this group identity and why were some of their characteristics preserved while others abandoned?

While "what" questions are relatively straight forward and have been studied by the generations of scholars who pointed out religion and geography as uniting factors and Hispanics, Arabs, Berbers, Jews and Saqaliba as contributing groups; the "why" questions are more ambiguous as they involve both individual and group interests and

ISSN: 0212-8594 ISSN-e: 2340-2776. № DOI: http://dx.doi.org/10.12795/rea.2014.i31.04

REA 31 (2014): 85-97

http://www.publius.us.es/estudios_andaluces 
an interplay between them. In order to uncover the dynamics of this interaction, we need to understand the reasons behind the human association in groups.

\section{GROUP IDENTITY AND ITS BONDS.}

Groupism is a central aspect of human evolutionary psychology.

Sociobiology (Allot, R., 1998) tells us that

[t]he readiness to form groups, both for the social animals and for early man, no doubt had its origin in the proto-family, the mutual dependence of the members of the family, emphasized by the long gestation and development periods of human infants. Human cultural/genetic evolution has come to take the form of natural selection of the group, survival of the fittest group; war developed as a cultural mechanism in the competition of groups (pseudospeciation) for space and raw materials. The group or supergroup is an instrument of survival, for protection against other groups or supergroups.

"Groupism" then as a primary human behavioral pattern is the readiness to form groups around any observed or imagined differences in bodily or mental characteristics; almost anything will serve: proximity, language, age, sexual inclination, skin color, eye and hair color, shared historical or individual experience, metaphysical beliefs, shared descent ... Those who consider themselves similar in some respect tend to aggregate, to form a herd or flock and in so doing immediately are distinguished from (more or less strongly) those who identify themselves with other groups.

Group affiliation in this context is purely voluntary, sought after by an individual for his own personal reasons, as opposed to formal group structures formed by a decision from outside, such as work groups, official organizations and alike. Since the word "group" is used in both cases, a more descriptive label might be more appropriate.

A few years ago David Ringrose introduced a helpful notion of affinity networks ${ }^{1}$ held together by informal bonds of affection, belief, family loyalty and common purpose (e.g. Jewish and Armenian diasporas, the catholic missionaries) (Ringrose, D., 2002). They are essentially the individuals and their decisions, personal goals and customary support systems that operate within and among urban networks without being identified with any particular one. A group of people only becomes an affinity network if they are able and willing to cooperate towards a common goal. Dale Eickelman has convincingly shown us that the local population of Boujad considered as a "quarter" only those neighborhoods that had a "man of word," who can mobilize the people in

\footnotetext{
${ }^{1}$ I prefer this type of group description to the social and ethnic groups because it is more general and emphasizes the basis of group solidarity ("affinity").
}

ISSN: 0212-8594 ISSN-e: 2340-2776. № DOI: http://dx.doi.org/10.12795/rea.2014.i31.04 
case of necessity: "preservation of darb is contingent on its effectiveness in an ongoing social situation" (Eickelman, D., 1974, 291). For example, the "guilds," sought after by so many Oriental scholars, cannot be considered an affinity network until later times because they did not represent a real association that was capable of an action in its interest. Similarly, the rural immigrants living on the outskirts of the city were not related by any form of affinity, and thus should not be associated together even though they had some common features.

The affinity bonds can be either unique, or combine several components: personal safety, a real or perceived tribal or blood closeness (qarba), a common religious belief, a material gain, power, a quest for knowledge, or all of the above. The mechanisms by which the loyalties had been formed in early Islamic society were studied by Roy Mottahedeh (Mottahedeh, R., 1980) who concluded that the ways by which the individuals in the society formed commitments to each other remained roughly the same for generations and "can account for the political life in this society as a whole" (Mottahedeh, R., 1980, 3). He maintains that

Most of [...] Near Eastern associations lacked formal internal structure, unless such structure was imposed by a central government... Social networks are only knit together, and social building blocks are themselves only built, by the fears and inclinations of the individuals who form them. (Mottahedeh, R., 1980, 4-5)

Mottahedeh acknowledges that "no sharp line can be drawn between ... deliberately acquired loyalties and loyalties of category" (Mottahedeh, R., 1980, 97) where the former represents "forms of obligations that men acquired by deliberate acts [of an oath of allegiance or a vow] and not through the aspiration of those men to a category," while the latter is "loyalties that men felt they owed each other because of their common participation in categories" (Mottahedeh, R., 1980, 6), i.e. the affinity networks in Ringrose's definition. The participation in these categories is a result of self-conscious identification of oneself with real or perceived attributes of a category. For example, a person's hasab (honor acquired through deeds) and nasab (genealogy) will together result in a certain tabaqah (ranked layer of the society) of a higher (khass - for men affiliated to the regime, and ra'iyah - not affiliated) or lower (amah) level. Khass could be further broken down into $\operatorname{sinf}$ (unranked social category) ${ }^{2}$ of clerks, soldiers, eunuchs, wives and boon companions, while ra'iyah may include 'ayn (chiefs of the community) (Chamberlain, M., 1994), tajir (great merchants) and ulama (scholars). People of the ammah layer could distinguish themselves by sina'ah (profession) and jins (ethnicity), where the former is a material attribute easy to

\footnotetext{
2 The two most important sinfs among the servants of the ruler were the clerks and the soldiers. (Mottahedeh, R., 1980, 108).
}

ISSN: 0212-8594 ISSN-e: 2340-2776. № DOI: http://dx.doi.org/10.12795/rea.2014.i31.04 
establish, while the latter is a good example of a perceived affinity. ${ }^{3}$ Recent studies on the nature of ethnicity and its relationship with culture have revealed that

[t]he construction of ethnicity is grounded in the shared subliminal dispositions of social agents which shape, and are reshaped by, objective commonalities of practice, i.e. the habitus. Such subliminal dispositions provide the basis for the recognition of commonalities of sentiment and interest, and the perception and communication of cultural affinities and differences. Consequently, the dichotomy between primordial and instrumental approaches to ethnicity can be transcended. (Jones, S., 1977, 128).

The nature of association, or affinity, can change over time, allowing affinity networks to formalize into formal institutions (e.g. the followers of the prophet Muhammad started as an informal association and ended up as a civilization). However, formalization is not always a good thing for affinity networks as it may lead to the loss of the initial affinity bonds and common purpose (e.g. the transformation of the magus into Zoroastrian clergy affiliated with Sassanian royalty but not with the masses). Affinity networks are effective as long as they stay in line with their goals and methods (e.g. The Jewish diaspora has prospered throughout the centuries without any attempt to formalize its status). If there is a common purpose, there will be natural leaders that would represent their networks; otherwise a lack thereof will lead to decrease of effectiveness and an eventual disintegration of the network.

Since in real life an individual plays more than one role he can simultaneously belong to several affinity networks, and represent himself differently when communicating on different levels. For example, an American of a Hispanic background would associate himself with the Hispanic community at home, but call himself an American when traveling abroad.

Throughout history, groups continuously mix and break up according to changes in the environment and migration patterns. When a new group identity, such as an Andalusian, was formed, how was the selection of group characteristics, values and behaviors made?

\section{THE BASIS FOR SELECTION OF FEATURES FOR A COMPOSITE GROUP IDENTITY.}

\section{All growth involves integrating apparent opposites - Anonymous}

\footnotetext{
${ }^{3}$ Ethnic identity: that aspect of a person's self-conceptualization which results from identification with a broader group in opposition to others on the basis of perceived cultural differentiation and/or common descent. Ethnicity: all those social and psychological phenomena associated with a culturally constructed group identity. The concept of ethnicity focuses on the ways in which social and cultural processes interact with one another in the identification of, and interaction between ethnic groups. (Jones, S., 1977).
}

ISSN: 0212-8594 ISSN-e: 2340-2776. № DOI: http://dx.doi.org/10.12795/rea.2014.i31.04

REA 31 (2014): 85-97

http://www.publius.us.es/estudios_andaluces 
According to Piaget's theory centered on cognitive development (Wadsworth, B., 2004), adaptation is the most important function of human functioning. Adaptation is the continuous process of using the environment to learn, and learning to adjust to the changes in the environment. The process of adjustment consists of two complementary processes: assimilation, and accommodation:

- Assimilation is the process of taking in new information and fitting it into a preconceived notion about objects in the world;

- Accommodation means adjusting to new experiences or objects by revising the old plan to fit the new information.

Assimilation and accommodation in each particular case are mutually exclusive, and it would be reasonable to assume that choice between assimilation and accommodation depends on the relative strength of the existing paradigm (skills, convictions, etc), and the new information, In the extreme case, when one of the sides is non-existent, the outcome is quite obvious. The choice between assimilation and accommodation also depends on the relative position of the subject of choice within the hierarchy of needs. ${ }^{4}$ For example, the need of the highest priority is nourishment and thus Arab irrigation techniques were adopted and new crops were brought to accommodate an increasing population. The next priority is security/survival and thus superior Berber military practices replaced the voluntary junds, while the medical knowledge of the indigenous Jews was maintained and built upon. When it comes to these first two groups of needs the choices are straight forward and make common sense. However, the choices in the second pair of groups of needs are more confusing as they deal with social aspects of the human personality: group vs. individual interest.

\section{GEOGRAPHY AND RELIGION AS A UNITING BASIS FOR THE ANDALUSIAN IDENTITY.}

\section{Die Religion ist das Opium des Volkes}

Karl Marx

The overwhelming majority of scholars agree that the main uniting forces in al-Andalus were the compact geography of the peninsula and the Muslim religion. The role of religion is particularly important because it was the main value basis for a pre-modern individual (Benaboud, M., 1984).

The twelfth century Andalusian philosopher ibn Tufail proposed the "Double Truth" theory: he felt that "philosophy was intended for the educated man; the common people should, however, be taught to respect established religion" (Irving, T., 1967,

\footnotetext{
${ }^{4}$ Abraham Maslow's hierarchy of needs organizes human needs in a descending order: 1) physiological needs: food, shelter etc.; 2) security/safety; 3) social needs: love and belonging; 4) ego needs: personal worth, esteem; 5) self-actualization. The higher needs take precedence over the lower ones, which are not addressed until the higher levers are satisfied. (Maslow, A. H., 1943).
}

ISSN: 0212-8594 ISSN-e: 2340-2776. № DOI: http://dx.doi.org/10.12795/rea.2014.i31.04

REA 31 (2014): 85-97

http://www.publius.us.es/estudios_andaluces 
65). Was it a subliminal lesson learned from the successes of the Muslim conquest of the Iberian Peninsula in the eighth century? While the real reasons for the conquest are still being debated, it is unlikely that they had a strong religious component. ${ }^{5}$ However, once settled, the Muslims for whom politics and religion was integrated, launched a wide-spread conversion campaign, with a remarkable result: by mid-ninth century $40 \%$ of the population had Muslim names (used as an indicator of conversion), and by the beginning of the twelfth century this number reached $80 \%$ (Bulliet, R., 1979). The results of this campaign were particularly impressive given the small number (initially, less than $1 \%)^{6}$ of the invaders vis-à-vis an indigenous Christian population of six or seven million.

Before invasion, the population of the Iberian Peninsula was mostly rural and their reasons for conversion were banal, but quite in line of Maslow's hierarchy (Maslow, A., 1949). Being dhimmi, (protected peoples) in the Muslim polity, the Christians did not have to worry about their safety or social acceptance. The fertile lands and irrigation systems spared them from hunger. Thus the next in line was the need for economic benefits. Glick agrees with Bulliet that "low-class people tended to convert first, in order to benefit from tax and other economic advantages, which accrue to them in a Muslim polity...although during the course of the country's rise to economic dominance in the western Mediterranean great numbers were attracted to the towns, where they swelled the ranks of the urban proletarian and artisan classes" (Glick, T., 1979, 187).

Some of them, or their children, studied to become ulama, or fuqaha, ${ }^{7}$ - an important grassroots affinity network in al-Andalus. As M'hammad Benaboud convincingly demonstrated, Maliki ulama "had deep popular roots in al-Andalus, and were generally of middle or lower class origin," they had "a high degree of flexibility and adaptation to social reality... their essential objectives in life were not materialistic... They enjoyed a priviledged social status ... based on their righteousness, ethical and moral behavior and their role as representatives of Islamic values, teaching and practices" (Benaboud, M., 1984, 110). Being in charge of the orientation of education and implementation of educational policies, they directly influenced the socio-cultural life of the majority of the population. It is important to stress the fact that their informal status and popular origin gave them more credibility within the majority of the rural community, than what they would have gained, had they been appointed from above and not chosen for their merits. Although the ulama were not formally organized, or military potent as, for example, the Berber coalition was, nevertheless they played an important role in the development of the Andalusian identity under the common umbrella of Islamic faith.

\footnotetext{
${ }^{5}$ See for example, Ibn Abd al-Hakam's "Narratives of the conquest of al-Andalus" in Constable, O. (1997)

6 "Tariq's original invasion force of 12,000 men was said to include but seven [Arabs]" (Glick, T., 1979, 179).

${ }^{7}$ The synonymy of these terms meaning "educated person, in religion and some other type of knowledge" was shown by Benaboud, M. (1984).
}

ISSN: 0212-8594 ISSN-e: 2340-2776. № DOI: http://dx.doi.org/10.12795/rea.2014.i31.04

REA 31 (2014): 85-97

http://www.publius.us.es/estudios_andaluces 
As a religion, Islam possessed another important feature, which ultimately led to unification of al-Andalus by further assimilation of the indigenous population. Since the Quran must be read in the original language, the newly converted subject had to learn the language as an immediate consequence of their conversion. Moreover, even nonMuslims had to learn the language as it was the official language of trade and administration. Even in the realms beyond practical necessity, the Arabic language was deemed fashionable. Paul Albar in his Indiculus Luminosus complained that the Christian youths of ninth century Cordoba were conversant with Arabic literature but could not speak their own tongue [Latin] (cited in Glick, T., 1979, 176).

Since religion and language are two most important attributes of the ethnic identity, what did happen with this type of group affiliation?

\section{THE ROLE OF ETHNIC IDENTITY AND ASABIYYA}

In the end, both sides are usually partially correct, but their error is that they try to be totally and exclusively right.

M’hammad Benaboud

As it was explained earlier, ethnic identification is a subjective construct; it is an aspect of a person's self-conceptualization which results from identification with a broader group in opposition to others on the basis of perceived cultural differentiation and/or common descent. The fourteenth century Andalusian intellectual giant Ibn Khaldun (Ibn Khaldun et al., 1967) had pinpointed this notion under the name of "asabiyya," often translated as "group solidarity," or later, more elegantly - "network affinity." Regardless of the name, the meaning indicates a feeling of belonging to a particular cultural group defined through a set of real and perceived attributes.

Nobody seems to argue against the fact that in the early eighth century there had been a clear division into the following ethnic groups: the Arabs, the Berbers, the Saqaliba, the Jews, and the indigenous Hispanic Iberians. The pivotal question, which is also relevant for the present discussion, is whether an eleventh century Andalusian felt an ethnic association with one of these groups. Here, the scholars part sides quite radically.

Sometimes relying on the same primary source (Ibn Hayyan) and talking about the same (Taifa) period, they argue for "political coalitions along ethnic lines" and "ethnically oriented kingdoms" (Glick, T., 1979, 181) or for the complete absence of asabiyya and prevalence of self-interest over ethnic affinity (Benaboud, M., 1980-81). Although most of Benaboud's premises seem correct, the conclusion does not really follow logically. For example, his argument against ascribing to a state a particular ethnic orientation (Arab, Berber or Saqaliba) is that all of them had other ethnicities in administration (such as Jews) and inhabitants. This argument would be valid of he

ISSN: 0212-8594 ISSN-e: 2340-2776. № DOI: http://dx.doi.org/10.12795/rea.2014.i31.04

REA 31 (2014): 85-97

http://www.publius.us.es/estudios_andaluces 
could prove that such "extra-ethnical" elements were implementing policies explicitly oriented against the ruler's own ethnic group. Another point presented by Benaboud is that Taifa leaders sometimes formed alliances with those of different ethnic or even religious affiliation. However, he does not mention that this occurs when the benefits (particularly, safety and survival - the higher category of the hierarchy of needs) of coalition with ex-ethical rulers overweighed those with the one of the same ethnicity. A cleaner example could have been to show, that when all other conditions are equal, the ruler chooses to affiliate with an ex-ethnical partner. The problem is that Benaboud is trying "to be totally and exclusively right" - a characteristic he ascribed to others but failed to escape himself.

At the end, he nevertheless tries to level off his position by stating that "Andalusian society... was ethnically heterogeneous, but socially integrated" (Benaboud, M., 1980$81,27)$. And maybe here, he is exactly right. The ethnical affiliations did not probably go away completely. However, their importance has lost relevance as the primary source of antagonism among groups (and since Benaboud interprets asabiyya exclusively in a destructive way, he is probably right) because it was no longer a period of survival, but the period of prosperity and thus, according to Maslow (Maslow, A., 1949), higher level social and ego needs took precedence. So, an Andalusian started to resemble an American of a Hispanic origin and consider himself Andalusian abroad, and a Berber in a neighborhood street fight.

\section{CREATING AN IMAGE OF AL-ANDALUS.}

O, inhabitants of Al-Andalus,

What happiness is yours having waters, shade, rivers and trees,

The Garden of Eternal Happiness is not without,

But rather within your territory;

If I had to chose, this is the place I would settle on.

Do not think that tomorrow you will go to Hell;

One does not enter into the Inferno after being in Paradise!

Ibn Khafaja, an eleventh century poet from Valencia

The manuscripts don't burn.

Mikhail Bulgakov

Now that we have reviewed the process of the formation of the group identity of an Andalusian and identified its main characteristics: Muslim faith, Arabic language and heterogeneous ethnicity, the question is what made it seem so different from other Muslim Arabic speaking communities elsewhere, and how this difference was manifested and transmitted.

ISSN: 0212-8594 ISSN-e: 2340-2776. № DOI: http://dx.doi.org/10.12795/rea.2014.i31.04

REA 31 (2014): 85-97

http://www.publius.us.es/estudios_andaluces 
Firstly, the advantage of the Andalusians was that they were actively seeking knowledge in the East and, therefore, could leap-frog the initial intellectual development stage. ${ }^{8}$ In a way, they carried on the legacy of al-Mamun's House of Knowledge into al-Andalus and were able to build original thinking upon it; often using original texts like al-Kindi did (Irving, T., 1967).

However, the role of ulama was not limited within the abstract philosophical arguments and religious discussions. "The Andalusian ulama did not remain indifferent to the widespread literary dynamism and productivity that characterized al-Andalus" (Benaboud, M., 1984, 113).

The contemporary literary critic Ibn Bassam incidentally referred to a category of poetscholars (al-ulama ash-shuara) when he compiled an anthology of Andalusian poetry in an effort to show its equality and even superiority to that of the East.

Indeed, new Andalusian poetry was different from the classical examples in a very peculiar way: it had a particular "Hispanic accent," which others could not possibly have had simply because one needs to be bi-lingual to write poetry equally easily in two languages. The Hispanic (or, Romance) influences in the Andalusian literature have been studied by the Russian philologist Alexander Kudelin who builds upon the theories of Ribera (Kudelin, A., 2003). In his analysis of the unique poetic forms of muwashshah and zajal invented in al-Andalus he stresses the fact that the mixing of the Arabic and Spanish forms occurred not only by a superficial inclusion of either the last part ("kharja" in muwashshah) or individual dispersed words (in zajal) in Romance language, but on a deeper contextual and structural level. For example, even when a poem is written in classical Arabic, its meter does not correspond to one of the sixteen aruds but has a syllabic structure like that of the poems in Romance languages.

In terms of style and content, in contrast with the classical Arabic gazal, which is in essence a "male" lyric, the Andalusian kharja is a "female" lament, usually written in Romance language (and only rarely in Arabic when the poem is a praise to the ruler). In the light of the "massive intermarriage of Arab men and Hispanic women" (Glick, T., $1979,186)$, it makes perfect sense and highlights the survival of ethnic identities even on this subliminal level.

On the other hand, the tripartite structure of some muwashshahat, that start with a nasib and end with a madih to the ruler strikingly resemble that of the Jahiliah qassidah. In this respect, the instruction of Ibn Sana al-Mulk to make the transition from the body of the muwashshah to kharja as contrasting as possible is particularly interesting, as it is exactly by its abruptness that the last part of the qassidah usually strikes us as readers.

\footnotetext{
${ }^{8}$ Even though Ibn Tufail argued in Hayy ibn Yaqzan that they would have reached the same result either way.
}

ISSN: 0212-8594 ISSN-e: 2340-2776. № DOI: http://dx.doi.org/10.12795/rea.2014.i31.04

REA 31 (2014): 85-97

http://www.publius.us.es/estudios_andaluces 
One can argue that the bilingual versatility of the Andalusians could have given them a valid reason to feel superior to others who could understand only a part of the muwashshah. Although some in the East tried to counter this poetic form with a kharja in Persian.

Another means of the Andalusian image transmission was visual arts, which the social scientists deem to be more influential than the oral traditions. Being closer to western Christendom and more influenced by it, al-Andalus had more freedom of creative expression and better access to important natural resources such as Italian marble, ivory and precious stones. Instead of writing quotes from the Quran or hadith on the buildings, or statements of ownership on portable objects, the Andalusians created "speaking objects."

Poets also extended paradisiacal perceptions of beauty and fertility to manmade objects in al-Andalus. Objects, humble and noble, were embellished with autonomous, poetic inscriptions that make them speak in such a way that the object praises itself in the absence of the poet. Not only objects were given selfconscious, autonomous verses in the first person, but also buildings whose inscriptions...praise themselves. The interaction then, between the viewer and the speaking object is dictated by the poet, who instructs the viewer through the object. (Ecker, H., 2004, 3).

For example, the ivory pixis carved by Khalaf for al-Hakam II for his concubine Subh bears an inscription: "The sight that I offer is the fairest of sights, the still firm breast of a lovely young woman. Beauty has bestowed upon me a robe clad with jewels, so I am a vessel for musk and camphor and ambergris." Or a poem of ibn Zamrak in the Mirador de Linderaja: "My charms are so extreme that even the stars on the distant horizon borrow them" (cited in Ecker, H., 2004). This was quite different from "There is no God but Allah", or even Tamerlane's "If somebody doubts our power - look at our buildings."

The most interesting part of this creative splash in the history of al-Andalus is that it occurred in, and because of the most disastrous political situation of the Taifa period. When the caliphate was disintegrated into dozens of small Taifa states, each party king launched a personal PR campaign by hiring poets and building palaces to enhance his own personal image. No wonder that these policies eventually ruined the economy and pushed them into complete political and economic bankruptcy in a matter of less than a century.

\section{CONCLUSION.}

Every cloud has a silver lining - a proverb

ISSN: 0212-8594 ISSN-e: 2340-2776. № DOI: http://dx.doi.org/10.12795/rea.2014.i31.04

REA 31 (2014): 85-97

http://www.publius.us.es/estudios_andaluces 
Al-Andalus continues to attract hundreds of scholars and millions of tourists. Its image fascinates us by its illusory ambiguity. Alas for Glick, we do not see Berber turbans and traces of Saqaliba. We experience al-Andalus as a coherent entity, which has many accents but is unique as a whole. Maybe it was not always a paradise for its inhabitants, but its idealized image will improve the lives of many others who would heal a nostalgia or source an inspiration from it. And maybe Benaboud is wrong and right at the same time, since by overspending on culture the Taifa rulers ended up acting not in their own interests but in the interest of a group identity of al-Andalus.

\section{BIBLIOGRAPHY}

Allot, R. (1998): "Group Identity and National Identity," presented at conference of European Sociobiological Society, Moscow.

www.percepp.demon.co.uk/groupnat.htm [June25, 2005].

Benaboud, M. (1980-81): "Asabiyya and social relations in al-Andalus during the period of the Ta'ifa States (11th century AD/5th century AH)", Hesperis Tamuda 19, 5-45.

Benaboud, M. (1984): "Socio-political role of Andalusian Ulama during 5th/11th century", Islamic Studies 2, 103-41.

Bourdieu, J. (1984): Distinctions. A Social Critique of the Judgment of Taste. Harvard University Press.

Bulliet, R. W. (1979): Conversion to Islam in the Medieval Period. Cambridge, Mass. and London: Harvard University Press. http://dx.doi.org/10.4159/harvard.9780674732810

Cavalli-Sforza, L. (2000): Genes, Peoples, and Languages, North Point Press (2000).

Chamberlain, M. (1994): Knowledge and Social Practice in Medieval Damascus, 11901350. New York: Cambridge University Press.

Constable O. R. ed. (1997): Medieval Iberia. Philadelphia: University of Pennsylvania Press.

Ecker, H. (2004): Caliphs and Kings: The art and influence of Islamic Spain. Washington, D.C.: University of Washington Press.

Eickelman, D. F. (1974): "Is There an Islamic City? The Making of a Quarter in a Moroccan Town," IJMES, 5, 274-94.

Glick, T. F. (1979): Islamic and Christian Spain in the Early Middle Ages. Princeton: Princeton University Press.

ISSN: 0212-8594 ISSN-e: 2340-2776. № DOI: http://dx.doi.org/10.12795/rea.2014.i31.04 
Ibn Khaldun, Rosenthal, F. and Dawood N.J., (1967): The Muqaddimah: An Introduction to History, Princeton University Press.

Irving, T.B. (1967): "The Process of Arab Thought in Spain," Studies in Islam 4, 65-96.

Jones, S. (1977): The Archaeology of Ethnicity, New York: Routledge.

Kudelin, A.B. (2003): "Arabo-Spanish Strophic as a mixed system." Arabskaya Literatura. Moscow: Yazyki Slavianskoi Kultury, 255-92.

Maslow, A. H. (1943): "A theory of human motivation", Psychological Review, 50(4), 370-96. http://dx.doi.org/10.1037/h0054346

Mottahedeh, R. (1980): Loyalty and Leadership in an Early Islamic Society. New Jersey: Princeton University Press.

Ringrose, D. R. (2002): "Beyond the Mediterranean: Europe Connects with the World, 1400-1700." Conference on Fernand Braudel, UCLA,

Wadsworth, B. J. (2004): Piaget's theory of cognitive and affective development: Foundations of constructivism. Longman Publishing.

ISSN: 0212-8594 ISSN-e: 2340-2776. № DOI: http://dx.doi.org/10.12795/rea.2014.i31.04 